\title{
Tube Dosing Unit
}

National Cancer Institute

\section{Source}

National Cancer Institute. Tube Dosing Unit. NCI Thesaurus. Code C48549.

A dosing unit equal to the amount of active ing redient(s) contained in a tube. 